\title{
Renal papillary necrosis
}

\author{
Stephen A. Gellera, Fernando P. F. de Campos ${ }^{b}$
}

Geller SA, Campos FPF. Renal papillary necrosis. Autopsy Case Rep [Internet]. 2013; 3(4): 69-71. http://dx.doi. org/10.4322/acr.2013.042

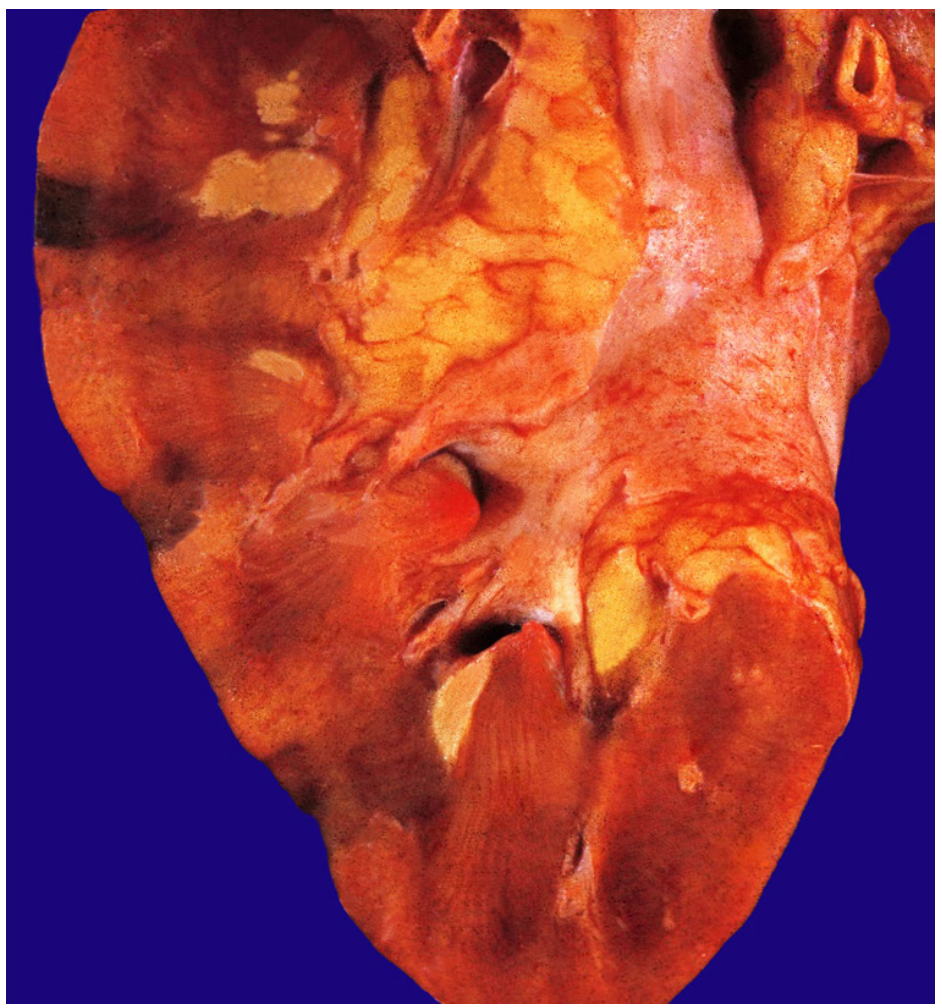

Picture provided by Dr. Stephen A. Geller - personal archive.

Figure 1 - Renal papillary necrosis. Irregularly round or oval areas of yellow necrosis are seen in renal papilla and medullary areas of the kidney from a 62-year-old female with type 1 diabetes mellitus. A urinary tract infection was also present as evidenced by the mildly inflamed renal pelvis epithelium (acute pyelitis).

In 1877, Dr. Nikolaus Friedreich ${ }^{1}(1825-$ 1882; student of Virchow who became Professor of Pathology at Heidelberg and who also described Friedreich's ataxia) first described renal papillary necrosis (RPN) in patients with prostatic hypertrophy and secondary hydronephrosis. Thereafter in 1937, Froboese ${ }^{2}$ and Günther ${ }^{3}$ emphasized the association of this entity with diabetes mellitus. These authors also observed renal papillary necrosis in cases of urinary tract obstruction even in the absence of diabetes mellitus.
In 1952, Mandel's ${ }^{4}$ report corroborated the latter findings, suggesting that urinary tract infection played a role in the pathogenesis of RPN. His report showed the presence of urinary infection in $95 \%$ of cases of RPN, in autopsy studies. It was in the late 1950s that analgesics emerged as a major etiological factor of RPN. ${ }^{5}$ Since then some series reported that analgesic abuse accounted for $80-90 \%$ of cases of RPN. ${ }^{5-7}$ In this setting non-steroidal anti-inflammatory drugs (NSAID) are also included with their incidence increasing

\footnotetext{
a Department of Pathology and Laboratory Medicine - Weill Medical College of Cornell University - New York - USA. ${ }^{b}$ Department of Internal Medicine - Hospital Universitário - Universidade de São Paulo, São Paulo/SP - Brazil.

Copyright $\odot 2013$ Autopsy and Case Reports - This is an Open Access article distributed of terms of the Creative Commons Attribution NonCommercial License (http://creativecommons.org/licenses/by/3.0/) which permits unrestricted non-commercial use, distribution, and reproduction in any medium provided article is properly cited.
} 
as these medications are more often utilized. The risk highest is for phenacetin (no longer used in many countries) and acetaminophen. In general, the risk for analgesic nephropathy is cumulative. More recently, it has been shown that these drugs are harmful to human kidneys in the presence of volume depletion, underlying renal disease as well as long-term abuse. ${ }^{8}$ Other causes of RPN include: sickle-cell hemoglobinopathies ${ }^{9,10}$, postrenal transplants ${ }^{11}$, chronic liver disease ${ }^{12}$, shock and severe dehydration, the latter mainly observed during infancy. ${ }^{5}$ Table 1.

The principal causes are summarized in

Table 1 - Major causes of renal papillary necrosis (RPN)

\section{Analgesic nephropathy}

Sickle cell nephropathy

Diabetes mellitus, often with urinary tract infection

Prolonged use of NSAIDs

An expanded list of causes is summarized with the English language mnemonic "POSTCARDS" (pyelonephritis, obstructive uropathy, sickle cell disease, tuberculosis, chronic liver disease, analgesic/alcohol, renal transplant rejection, diabetes mellitus, systemic vasculitis). ${ }^{13}$

The frequency of RPN in different disease conditions is unknown because of underdiagnosed pauci- or asymptomatic cases. However approximately $30 \%$ of all cases of RPN occur in the setting of diabetes mellitus. In these cases, hyperglycemia is usually uncontrolled, and urinary tract infections are frequently seen. The relationship of RPN with diabetic microangiopathy could be demonstrated either in vivo or in an autopsy series. ${ }^{14}$

Friedreich ${ }^{5}$ proposed a vascular mechanism to explain the RPN regardless of underlying disease. Unequivocally, this mechanism is observed in sickle cell disease, where vasa recta are obstructed by the sickling erythrocytes. In case of analgesics and NSAID, ischemia can be demonstrated in the medulla and vasa recta due to direct inhibition of cyclooxygenase-mediated production of prostaglandins. ${ }^{8}$ A direct toxic effect on cells of the medulla is also involved in the pathogenesis of RPN. Damage to these cells may similarly reflect as effects on vasculature, since medullary interstitial cells synthesize prostaglandins. Studies have also shown that ischemia results from direct endothelial cell damage. ${ }^{15}$ Regardless the involved mechanism, the end result is reduced prostaglandin production, leading to decreased vascular perfusion, vasoconstriction and eventually ischemic necrosis. ${ }^{8}$

The lack of specific symptoms, in the early stages, makes diagnosis challenging. Later clinical features include: nocturia, dysuria, pyuria, hematuria (most notably microscopic hematuria), ureteral colic, necrotic papillae voided in the urine ${ }^{6}$ and back pain. Renal function studies may also reveal decreased glomerular filtration rate (GFR), increased urea blood nitrogen (BUN) and renal tubular acidosis. Eventually RPN leads to death or chronic renal failure. ${ }^{8}$

Histologically, renal papillary necrosis is characterized by coagulative necrosis of the renal papilla and the background medullary pyramids. Subsequently the necrotic foci can become infected either from ascending cystitis or hematogenous dissemination and be seen as acute liquefactive necrosis with potential abscess formation. The papilla, whether infected or not, can cause renal tubular obstruction. Sloughed papilla can be seen in cytopathology preparations of urine. In time fibrosis and calcification occur. Bilateral involvement, or involvement of a solitary kidney, can lead to renal failure. If renal papillary necrosis is complicated by infection can lead to death, particularly in the diabetic patient who may or may not have other significant medical problems. Even in the non-diabetic patient, renal papillary necrosis is potentially fatal.

As a last note, it has been suggested that the first description of RPN is in the record of Beethoven's autopsy. ${ }^{16}$ The translation of the original Latin of the report says, "every one of their calices was occupied by a calcareous concretion of a wart-like shape and is large as a split pea." In a subsequent paper ${ }^{17}$, the wording of the translation was changed to "every single calyx was filled with a calcareous concretion like a pea which had been cut across the middle." In addition, the renal capsule is described as a "cellular membrane of an inch thick," indicative of chronic renal inflammation rather than acutely occurring RPN. This may, instead of RPN, be a description of extensive nephrolithiasis in association with chronic pyelonephritis. When RPN develops it is typically irregular and does not affect "every single" papilla. Further the necrotic papilla slough and break off, to be excreted, and evidence would similarly not be present throughout. "Wart- 
like," the descriptive term used, is not likely to be RPN, and, although color descriptors appear in other parts of the report, there is no use of "yellow," typical of necrosis, in the kidney section. The pathologist, Johann Wagner, was experienced and highly regarded, including by his student Karl von Rokitansky, developer of the great Viennese school of pathology. As was the custom of the time the report concentrates on explaining clinical problems and the prostate gland, likely enlarged in a 57 year old man and possibly the cause of at least partial obstruction and subsequent pyelonephritis, is not mentioned. In addition it is highly unlikely that he would have mistaken the papilla for a calyx, since the anatomy of the kidney had been well described by Marcello Malpighi (1628-1694) two centuries before.

\section{Keywords: Kidney Papillary Necrosis;} Diabetes Mellitus; Urinary Tract Infections; Antiinflammatory Agents, Non-Steroidal.

\section{REFERENCES}

1. Friedreich $\mathrm{N}$. Über Necrose der Nierenpapillen bei Hydronephrose. Virchows Arch Pathol Anat. 1877;69:30812. http://dx.doi.org/10.1007/BF02326121

2. Froboese C. Uber sequestrierende Marknekrosen der Nieren bei Diabetes Mellitus. Verh Deutsch Ges Pathol. 1937;30:431-43.

3. Guenther GW. Die Papillennekrosen der Niere bei Diabetes. München Med Wschr. 1937;84:1695.

4. Mandel EE. Renal medullary necrosis. Am J Med. 1952;13:322-7. http://dx.doi.org/10.1016/0002-9343(52)902866

5. Renal papillary necrosis. Lancet. 1982;320:588-90. http:// dx.doi.org/10.1016/S0140-6736(82)90665-1

\section{Stephen A. Geller, M.D.}

Department of Pathology and Laboratory Medicine

Weill Medical College of Cornell University

New York - USA

geller16st@gmail.com

\section{Fernando P. F. de Campos, PhD}

Department of Internal Medicine

Hospital Universitário - USP

São Paulo/SP - Brazil

fpfcampos@gmail.com
6. Harvald B. Renal papillary necrosis. A clinical survey of sixty-six cases. Am J Med. 1963;33:481-6. http://dx.doi. org/10.1016/0002-9343(63)90147-5

7. Hultengren N. Renal papillary necrosis. A clinical study of 103 cases. Acta Chirurg Scand. 1961;277:1-84.

8. Brix AE. Renal papillary necrosis. Toxicol Pathol. 2002;30:6724. http://dx.doi.org/10.1080/01926230290166760

9. Harrow BR, Sloane JA, Liebman NC. Roentgenologic demonstration of renal papillary necrosis in sickle cell trait. N Engl J Med. 1963;268:969. PMid:13953018. http://dx.doi. org/10.1056/NEJM196305022681802

10. Voulgarelis M, Ziakas P. Renal papillary necrosis unmasking sickle cell disease. N Engl J Med. 2005;352:1237. PMid:15788500. http://dx.doi.org/10.1056/NEJMicm030682

11. Edmondson RPS, Fawcet TW, Jones NF, Cade R, Tarrant DG, Juncos LI. Papillary necrosis in a transplanted kidney. $\mathrm{Br}$ Med J. 1972;1:547. http://dx.doi.org/10.1136/bmj.1.5799.547

12. Edmondson HA, Reynolds TB, Jacobson HG. Renal papillary necrosis with special reference to chronic alcoholism. Arch Intern Med. 1966:118:255. PMid:5947305. http://dx.doi. org/10.1001/archinte.1966.00290150069013

13. Powell C, Donohoe JM, Mydlo JH. Papillary necrosis [Internet]. Medscape; 2012. [cited 2013 Oct 2]. Available from: http:// emedicine.medscape.com/article/439586-overview\#a0102

14. Groop L, Laasonen L, Edgren J. Renal papillary necrosis in patients with IDDM. Diabetes Care. 1989;12:198-202. http://dx.doi.org/10.2337/diacare.12.3.198

15. Wolf DC, Turek JJ, Carlton WW. Early sequential ultrastructural renal altrations induced by 2-bromoethylamine hydrobromide in the Swiss ICR mouse. Vet Pathol. 1992;29:528-35. http:// dx.doi.org/10.1177/030098589202900607

16. Schwarz A. Beethoven's renal disease based on his autopsy: a case of papillary necrosis. Am J Kid Dis. 1993;21:643-52. PMid:8503419.

17. Davies PJ. Beethoven's nephropathy and death: discussion paper. J Roy Soc Med. 1999;86:159-61. 
